\section{Conceptualization of Dental Caries by Undergraduate Dental Students from the First to the Last Year}

Naiara de Paula Ferreira-Nóbiloº ${ }^{1}$ Maria da Luz Rosário de Sousa ${ }^{1}$, Jaime Aparecido Cury ${ }^{2}$
'Department of Community Dentistry, Piracicaba Dental School, UNICAMP - University of Campinas, Piracicaba, SP, Brazil ${ }^{2}$ Department of Physiological Sciences, Piracicaba Dental School, UNICAMP - University of Campinas, Piracicaba, SP, Brazil

Correspondence: Maria da Luz Rosário de Sousa, Avenida Limeira 901, Caixa Postal 52, 13414-903 Piracicaba, SP, Brasil. Tel.: +55-19-2106-5364. e-mail: luzsousa@fop.unicamp.br
Dental caries, still one of the most common diseases affecting people around the world, has a multifactorial nature encompassing necessary (biofilm accumulation), determinant (exposure to sugars and fluoride) and modulating factors (biological and social). The concepts about caries learned at dental schools may directly influence the conduct of the future dentists regarding the control and treatment of this disease. The aim of this study was to determine the concept that students at the Piracicaba Dental School, University of Campinas, Brazil, have about dental caries. In this cross-sectional descriptive study, 274 students answered the discursive question "Conceptualize dental caries". Students' answers were analyzed by a content analysis technique that allowed the creation of response categories and classification of the concepts in categories. Frequencies were expressed as absolute numbers and percentages. Differences between the responses according to the students' class years were tested by the chi-square test. Differences with $p<0.05$ were considered statistically significant. The response categories were: biological concept (53.6\%), restrictive multifactorial concept (12.1\%), comprehensive multifactorial concept (8.1\%), transmissibility concept $(15.8 \%)$, and other $(10.4 \%)$. Differences in response category frequencies were seen between the class years $(p<0.001)$. There was no consensus on the disease definition, although students predominantly had a biological concept of dental caries.
Key Words: dental caries, dental students, concept formation.

\section{Introduction}

The scientific concepts acquired while learning develop into the reflective consciousness and, subsequently, become spontaneous concepts (1). Conceptualization is not restricted to knowing how to define a certain phenomenon, but also includes understanding its history and determinants (2). Through the analysis of concepts, we are able to delineate the attributes or characteristics of the studied phenomenon because the concept itself is an abstraction that reflects the dynamism of the context (3).

Cariology is the science of dental caries and related factors. The knowledge base concerning Cariology has expanded over time, marked by a clear separation between the restorative and preventive dental fields (4-6). As a result of this dichotomy, several conceptualizations about caries have arisen. An important milestone in Cariology was met in the 1960s, with the proposal of the triad of Keyes (7). This concept attempted to encompass all of the caries-related knowledge that was available at that time. Three factors (host, microbiota and substrate) were identified as being essential for caries occurrence. They were schematically illustrated as a Venn diagram of overlapping circles whose common area represented disease occurrence (8).

This reductionist concept of caries suggested that control of any one of the factors would be sufficient to prevent the disease. Therefore, researchers sought ways to make the tooth more resistant to acids produced by oral bacteria from sugar fermentation or to eliminate Streptococcus mutans, the bacterial species associated with caries. A modification of the triad of Keyes concept was proposed by Newbrum (9), who added a time factor to the analysis because caries is a chronic disease and its signs or symptoms on dental surface take time to be detected clinically. In fact, the time for the onset of caries disease and for appearance of lesions (cavitation or early signs) is not clearly distinguished.

Dental caries is currently conceptualized as a multifactorial disease involving the known biological factors and social modifying factors such as education, social class, behavior, attitude (10). However, pragmatically it should be considered a biofilm (dental plaque) sugardependent disease (6), since caries lesions develop on dental surfaces where biofilm (necessary factor) is accumulated for a long period of time. However, biofilm accumulation alone is not sufficient for manifestation of the disease; daily exposure to dietary sugars (mainly sucrose) is the negative determinant factor responsible for the process of the disease and the changes made on the dental structure. Fluoride use, counter-balancing the detrimental effect of sugars, is considered a positive factor responsible for 
caries reduction worldwide. However, despite the advanced state of knowledge in the field of Cariology, conceptual understandings of the disease remain centered on the previously held dogmas (e.g., triad of Keyes). Furthermore, there is no consensus among professionals on a definition for the disease.

Conceptualizations about the disease held by professionals may affect their daily practices and conversely, existing practices may affect concepts about the disease (11). To address these concerns, this study aimed to determine the conceptualization that undergraduate dental students of the Piracicaba School of Dentistry, University of Campinas (FOP/UNICAMP) have about caries disease.

\section{Material and Methods}

A descriptive, quantitative and qualitative crosssectional study was conducted among students of all years of graduation (first, second, third and fourth year; 320 enrolled students) at FOP/UNICAMP after approval of the research protocol by the local Ethics Committee (Registration number 006/2010). Data collection was performed through the use of a single discursive question, $\vec{s}$ "Conceptualize dental caries", which was presented to students in the classroom during the last academic month of 2010.

Responses to the discursive question were analyzed by the content analysis technique $(12,13)$. The analysis procedure included the following steps: reading the concepts produced by the respondents; creating significance categories based on the concepts presented; classifying concepts according to created categories (with $>1$ answer was accepted); and statistically processing the data (Statistics 17; SPSS Inc., IBM Company, Armonk, NY, USA).

The frequencies of the variables were expressed as absolute numbers and percentages, $n(\%)$. Possible differences in the responses of the students relative to their year of school were assessed by the chi-square test, with a significance level of $5 \%$. multiple categories. Among the concepts mentioned by the students, most cited the biological concept, followed by the transmissibility concept and the strict multifactorial concept (Table 2).

\section{Discussion}

Given the wide scope of this subject, it is important to consider the methodological approach used in this study. The use of a discursive question prompts the respondent to reflect upon, organize and synthesize the information that he or she holds, without the subjectivity of his or her own judgment. However, although the question asked in this study may provide clues about the profile of the professional practice formed by graduates of this institution with respect to the prevention and treatment of caries, the question does not allow a detailed understanding of the knowledge of dental caries. To address this question, other methods would be needed to assess the different nuances of this topic.

The diversity of concepts presented by the students reflects the historical perspective of the evolution of theories used to explain the disease process (11). However, the concepts were largely compartmentalized and there

Table 1. Categorization of concepts

\begin{tabular}{lc}
\hline Category of answer & \multicolumn{1}{c}{ Central aspects of response } \\
\hline Biological concept & $\begin{array}{l}\text { Sugar- and biofilm-dependent disease or } \\
\text { references to DE-remineralization process }\end{array}$ \\
$\begin{array}{l}\text { Transmissibility } \\
\text { concept }\end{array}$ & Infectious disease transmitted by bacteria \\
$\begin{array}{l}\text { Strict multifactorial } \\
\text { concept }\end{array}$ & Triad of Keyes or Modified triad of Keyes \\
$\begin{array}{l}\text { Comprehensive } \\
\text { multifactorial concept }\end{array}$ & $\begin{array}{r}\text { Citation of multiple factors considering } \\
\text { the social determinants of disease }\end{array}$ \\
Other &
\end{tabular}

\section{Results}

A total of 274 students answered the question (response rate: $85.6 \%$ ), including 72 first-, 76 second-, 74 third- and 52 fourth-year students. From the analysis of the reply contents, the concepts produced by the students were grouped into five categories: biological concept; transmissibility concept; strict multifactorial concept; comprehensive multifactorial concept; and other (Table 1). The response from a single respondent could fall into 60
Table 2. Concepts of dental caries by undergraduate students from the first to the last year of the course

\begin{tabular}{lccccc}
\hline Concepts* $^{*}$ & 1st Year & 2nd Year & 3rd Year & 4th Year & Total \\
\hline Biological concept & $45(54.2)$ & $55(52.9)$ & $46(52.9)$ & $40(54.8)$ & $186(53.6)$ \\
Transmissibility concept & $4(4.8)$ & $13(12.5)$ & $23(26.4)$ & $15(20.5)$ & $55(15.8)$ \\
Strict multifactorial concept & $8(9.7)$ & $25(24.0)$ & $4(4.6)$ & $5(6.9)$ & $42(12.1)$ \\
Multifactorial concept & $6(7.2)$ & $6(5.8)$ & $4(4.6)$ & $12(16.4)$ & $28(8.1)$ \\
Other & $20(24.1)$ & $5(4.8)$ & $10(11.5)$ & $1(1.4)$ & $36(10.4)$ \\
\hline
\end{tabular}

Data are shown as number (percentage). $\chi^{2}=65.062, p<0.001$. * More than one answer was possible for each response. 
was a predominance of biological concepts in the students' answers.

The development of the microbiology field led by Louis Pasteur in the 19th century, which was motivated by the segmentation and fragmentation of knowledge since the creation of the scientific method, ushered into the so-called Bacteriological Era. This scientific era was characterized by an unrealistic expectation that all diseases could be eradicated by the centralization of efforts on biological aspects (14). The conceptualization of dental caries requires biofilm and sugar, which represent a necessary factor and a negative determinant of the disease, respectively. The specific location of disease development (tooth/ tooth surface) is understandable, given the imbalance of demineralization-remineralization (DE-RE) processes that occurs in the complex tooth-oral environment. However, this strictly biological understanding of dental caries is insufficient because it does not consider other factors related to the disease, such as fluoride, saliva and social factors. FOP/UNICAMP is one of the largest research centers for Cariology in Brazil, and the work performed at FOP/UNICAMP Laboratory of Biochemistry is referenced worldwide. These facts may explain why more than half $(53.6 \%)$ of the students in this institution had a biological concept of dental caries.

The erroneous concept of the disease transmissibility of caries was persistent among the students (indicated by $15.8 \%$ of respondents). Students expressed the concern (or reported as a fact) that bacteria from the oral cavity of the mother or caregiver of a newborn are transmitted to the child's mouth. Bacteria associated with caries development are inherent in the human and eventually colonize the oral cavity. Moreover, although bacteria can be transmitted, their presence per se does not result in disease development.

The biological perception of dental caries by FOPUNICAMP undergraduate dental students was reinforced by responses that referred to the triad of Keyes (the strict multifactorial concept), which were provided by $12.1 \%$ of students. This concept was an important milestone for Cariology as a science, but today it is considered to be unsatisfactory because it is extremely reductionist in its approach. Fewer than 10\% of respondents presented a more elaborate conceptualization of dental caries (comprehensive multifactorial concept), considering it a multifactorial process resulting from the interrelation of biological and biochemical factors (biofilm, diet, DE-RE process) with social factors (15).

Other investigations that studied health conceptualizations also found a predominance of the biological framework. Nunes and Freire (11) investigated conceptualizations of health among dental students at three dental schools in the State of Goiás, Brazil. They observed the predominance of physiological and functional concepts over social factors. The same findings were noted in a study of health concepts performed with teachers and primary school students from 10 public and private schools in Rio de Janeiro (2). Similar data emerged in a survey of students from four universities in the state of Rio de Janeiro, Brazil, in various courses, who demonstrated a fragmented and reductionist vision of health and disease (16).

The biomedical concept of disease remains dominant in health practices and education, despite efforts to move this concept towards a more comprehensive and interdisciplinary understanding (17-19). The persistent value placed on the biomedical model reflects the overvaluation of biological conditions and compartmentalization of the disease. The concept of health promotion has been replaced by a professional practice based on a model in which technique and individual attention prevail (11).

Although a low percentage of students overall responded with a multifactorial concept of disease, this percentage was highest in the final year, which may indicate a tendency towards a discrete change in the perception of these students at the end of their course. The concepts presented by the respondents reflected the organization of the dental educational curriculum. The curriculum is indicative of the values of the profession. In recent years, knowledge has been fragmented under the justification of the need for a deeper understanding (20). However, despite a deeper understanding, the object of knowledge has not been restored (21).

To change the current state of education, there is an urgent need for an interdisciplinary approach, without which there will be continued emphasis on biomedical contents over their intersection with the social sciences (22). At the research institutions, the curriculum is characterized by interdisciplinarity. However, given the diversity of concepts produced by students, there is a need for unity of thought among the professors.

This research methodology could be applied in other educational scenarios. In addition, it would be useful to develop more specific instruments, such as a structured questionnaire, to assess the overall knowledge of dental caries, in order to obtain other data on this subject.

There was no consensus on the disease definition, although FOP/UNICAMP undergraduate dental students predominantly had a biological concept of caries disease.

\section{Resumo}

A cárie dentária, uma das doenças mais comuns do mundo, tem caráter multifatorial englobando fatores necessários (acúmulo de biofilme), determinantes (exposição a açúcares e fluoretos) e moduladores (biológicos e sociais). Os conceitos sobre a doença incorporados durante a formação dos profissionais podem direcionar o tipo de conduta que será adotada pelos mesmos no controle e tratamento da cárie. 0 objetivo deste trabalho 
foi verificar a conceituação dos estudantes da Faculdade de Odontologia de Piracicaba da Universidade Estadual de Campinas sobre cárie. Neste estudo descritivo transversal, 274 estudantes responderam à questão discursiva 'conceitue cárie dentária'. As respostas foram analisadas pela técnica da análise de conteúdo que permite a criação de categorias de resposta e classificação dos conceitos em categorias. As frequências foram expressas em números absolutos e percentuais. As diferenças entre as respostas de acordo com o ano de curso dos estudantes foram testadas pelo teste do qui-quadrado. Diferenças com $p<0,05$ foram consideradas estatisticamente significantes. As categorias de resposta foram: conceito biológico $(53,6 \%)$, conceito multifatorial restritivo $(12,1 \%)$, conceito multifatorial abrangente $(8,1 \%)$, conceito de transmissibilidade $(15,8 \%)$, e outros $(10,4 \%)$. Foram encontradas diferenças nas categorias de resposta dos alunos dos diferentes anos de graduação cursados $(p<0,001)$. Não houve consenso na definição da doença, embora o conceito biológico da cárie dentária tenha predominado entre os estudantes.

\section{Acknowledgements}

The study was supported by a scholarship to the first author granted by The São Paulo State Research Foundation - FAPESP (Grants 2009/12370-1 and 2011/24042-9).

\section{References}

1. Batista CG. Concept formation in blind children: theoretical questions and educational implications. Psic Teor e Pesq 2005;21:7-15.

2. Boruchovitch E, Sousa IC, Schall VT. The concept of disease and of the preservation of health in a sample population of teachers and pupils of a school course for 7-14 year olds. Rev Saude Publica 1991;25:418-425.

3. Rodgers BL. Concepts, analysis and the development of nursing knowledge: the evolutionary cycle. J Adv Nurs 1989;14:330-335.

4. Löe H. Changing paradigms in restorative dentistry. J Amer Coll Dentists 1995;62:31-36.

5. Clark TD, Mjör IA. Current teaching of cariology in North American dental schools. Operat Dentistry 2001;26:412-418.

6. Cury JA, Tenuta LMA, Serra MC. Paradigms in Teaching Cariology. In: Fernandes CP (org). A world class dentistry. FDI 2010 Brazil. São Paulo: Santos; 2010. 374p.
7. Keyes PH. Recent advances in dental research: bacteriology. Int Dent J 1962;12:443-464.

8. Usha C, Stahyanarayanan R. Dental caries - a complete changeover (Part I). J Conserv Dent 2009;12:46-54.

9. Newbrum E. Cariology. $2^{\text {nd }}$ ed. Baltimore: Williams \& Wilkins, 1983. $389 \mathrm{p}$.

10. Fejerskov 0. Changing paradigms in concepts on dental caries: consequences for oral health care. Caries Res 2004;38:182-191.

11. Nunes FCS, Freire MCM. Concepts of health among dental students. Arq Odontol 2008;44:5-12.

12. Caregnato RCA, Mutti R. Qualitative research: discourse analysis versus content analysis. Texto Contexto Enferm 2006;15:679-684.

13. Rocha $D$, Deusdará B. Content analysis and discourse analysis: approaches and departures in the (re)construction of a trajectory. ALEA 2005;7:305-322.

14. Sevalho G. A historical approach to social representations of health and disease. Cad Saude Publica 1993;9:349-353.

15. Gomes D, Da Ros MA. The etiology of caries: the construction of a thought-style. Cienc Saude Coletiva 2008;13:1081-1090.

16. Andrade Júnior $H$, Souza MA, Brochier Jl. Social representation of environmental education and health education in college. Psicol Reflex Crit 2004;17:43-50.

17. Brazil. Law 9394/96, issued December 20, 1996. Law of Guidelines and Bases of the National Education. Diário Oficial da União 1996; 20 dez.

18. Brazil. March 4, 2002. Ministry of Education. National Council of Education. Chamber of Superior Education. National Curricular Guidelines for Graduation in Dentistry. Diário Oficial da União 2002; 4 mar.

19. Vilela EM, Mendes IJM. Interdisciplinarity and health: a bibliographical study. Rev Lat Am Enferm 2003;11:525-531.

20. Campos CMS, Soares CB, Trapé CA, Silva BRB, Silva TC. The relationship theory-practice and the teaching-learning process in a Collective Health nursing course. Rev Esc Enferm USP 2009;43:1226-1231.

21. Anastasiou LGC. The teaching in higher education: challenges and possibilities. ForGRAD em Rev 2006;1:5-8.

22. Nunes ED. The social sciences in health: thoughts about the origins and construction of a field of knowledge. Saude Soc 1992;1:59-84.

Received October 22, 2013 Accepted November 22, 2013 